\title{
Nurse researchers and nursing assistants: construction and projection of polymorphous identities
}

\author{
Enfermeiro pesquisador e enfermeiro assistencial: construção e projeção de identidades polimorfas \\ Enfermero investigador y enfermero asistencial: construcción y proyección de identidades polimorfas
}

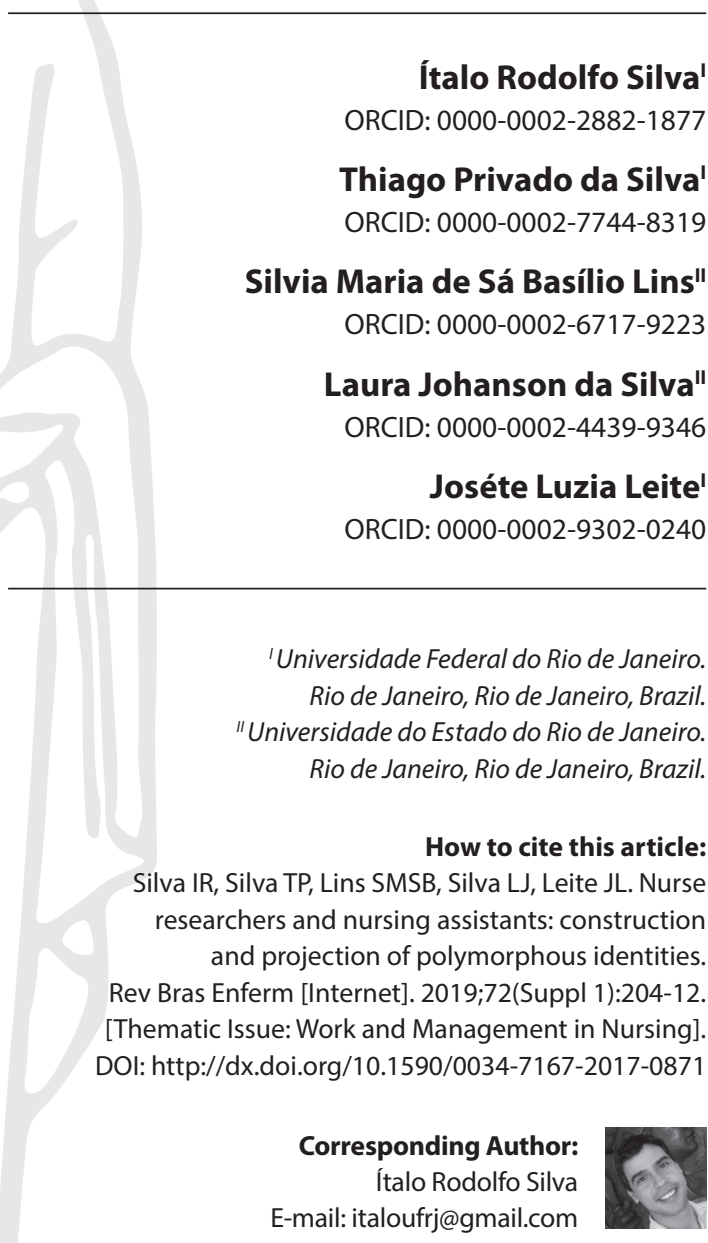

Submission: 01-23-2018

Approval: 05-15-2018

\section{ABSTRACT}

Objective: To understand the meanings that nurse researchers and nursing assistants attribute to one another, and to the development of research produced by Nursing. Method: Qualitative research. The Grounded Theory and the Complexity Theory were used as theoretical and methodological frameworks, respectively. Ten nursing assistants and six research nurses participated in the research. The semi-structured interview was used as a data collection technique. The results were categorized by comparative analysis and validated by ten judges. Results: The valuation of nursing care research as well as interactions between research development and nursing care may be related to the way nursing assistants and nurse researchers perceive themselves. These perceptions are multifaceted. Conclusion: The meanings nurse researchers and nursing assistants attribute to each other reveal mechanisms of closeness and distance between these actors, as well as between research and nursing care.

Descriptors: Knowledge Management; Nursing; Search; Nursing Research; Research Support as Topic.

\section{RESUMO}

Objetivo: Compreender os significados que enfermeiros pesquisadores e enfermeiros assistenciais atribuem um ao outro, e ao desenvolvimento da pesquisa produzida pela Enfermagem. Método: Pesquisa qualitativa. A Teoria Fundamentada nos Dados e o Teoria da Complexidade foram utilizados como referenciais teóricos e metodológicos, respectivamente. Participaram da pesquisa dez enfermeiros assistenciais e seis enfermeiros pesquisadores. A entrevista semiestruturada foi utilizada como técnica de coleta de dados. Os resultados foram categorizados por análise comparativa e validados por dez juízes. Resultados: A valorização da pesquisa por enfermeiros assistenciais, bem como interações entre o desenvolvimento da pesquisa e assistência de enfermagem pode estar relacionado à forma como enfermeiros assistenciais e enfermeiros pesquisadores se percebem. Essas percepções se apresentam de forma multifacetada. Conclusão: Os significados que enfermeiros pesquisados e enfermeiros assistenciais atribuem um ao outro revelam mecanismos de aproximação e distanciamento entre esses atores, bem como entre a pesquisa e a assistência de enfermagem.

Descritores: Gestão do Conhecimento; Enfermagem; Pesquisa; Pesquisa em Enfermagem; Apoio à Pesquisa como Assunto.

\section{RESUMEN}

Objetivo: Comprender los significados que enfermeros investigadores y enfermeros asistenciales atribuyen el uno al otro, y al desarrollo de la investigación producida por la enfermería. Método: Investigación cualitativa. La Teoría Fundamentada en los Datos y el Paradigma de la Complejidad se utilizaron como referenciales teóricos y metodológicos, respectivamente. Participaron de la investigación diez enfermeros asistenciales y seis enfermeros investigadores. La entrevista semiestructurada fue utilizada como técnica de recolección de datos. Los resultados fueron categorizados por análisis comparativos y validados por diez jueces. Resultados: La valoración de la investigación por enfermeros asistenciales, así como interacciones entre el desarrollo de la investigación y asistencia de enfermería puede estar relacionado a la forma como enfermeros asistenciales y enfermeros investigadores se perciben. Estas percepciones se presentan de forma multifacética. Conclusión: Los significados que enfermeros encuestados y enfermeros asistenciales atribuyen uno al otro revelan mecanismos de aproximación y distanciamiento entre esos actores, así como entre la investigación y la asistencia de enfermería.

Descriptores: Gestión del Conocimiento; Enfermería; Investigación; Investigación en Enfermería; Apoyo a la Investigación como Asunto. 


\section{INTRODUCTION}

Scientific research, like science, becomes a multifaceted phenomenon for the dimension of meanings about its essence and value ${ }^{(1)}$, in order to interfere with the projected image of its objects when questions are asked, such as: For whom the surveys are produced? How are these surveys consumed? Who is the researcher? Where does he/she speak from?

In Nursing, these issues converge to the importance of knowing the meanings that nursing assistants attribute to nurse researchers and the research they produce, as well as the meanings they attribute to nursing assistants, in the context of the consumption and development of researches. It is clear from this phenomenon, the quality in the interactions that influence the science of Nursing ${ }^{(2-3)}$.

For the above problem, therefore, it is important to understand polymorphous identity, a term sustained by complex thinking, in which the other/subject means both similar and dissimilar. It is defined as being closed or open at the imminence of the multiple unit of the subject, where its understanding is conditioned to the field of intersubjectivity ${ }^{(4)}$. In other words, it is important to consider, for the progress of nursing science, the meanings that reveal the perception of the nurse researchers and caregivers as pairs belonging to the same system, or even the factors that support the perception of both as isolated subjects. From these perceptions, there may be mechanisms that bring or distance research results from the nursing care context.

The polymorphic character rests, in this sense, on the ability to assume different facets for the construction of a meaning or projection of perception. For the phenomenon in question, polymorphous identity is based on the psychological and sociocultural dimensions of knowledge, which together form the organic sense of otherness ${ }^{(5-7)}$, thus substantiating the importance of considering experiences, beliefs, meanings and contexts with which nurses conceive the practice and consumption of research, as well as the researcher's role in nursing in order to develop strategies that are favorable to the connections between research and the care dimension ${ }^{(8-9)}$.

In this sense, among the factors that can influence nursing research consumption are the systems of meanings that nurses attribute to scientific practice, as well as the inherence of research products to their work process ${ }^{(8)}$. However, these meanings may have, as support, the quality of the interactions established between the nurse practitioner and the nurse researcher and, in parallel, the visibility and importance they attribute to one another in the process of producing and consuming research.

Thus, by pointing out divergent aspects to what and for whom nursing research is produced, in addition to assigning meanings to the nurse researcher's involvement with the Nursing care dimension and, at the same time, to recognize the potential of these researchers for the transformation of reality who live in the work process, nursing assistants can conceive of singularity and subjectivity in the way they perceive and project the other ${ }^{(10)}$, thus directing the dimension of otherness in social relations of work.

In spite of this, it is emphasized that, from the earliest Freudian formulations to Lacan's postulates, otherness has been signaling topics that lead to the idea that the subject is constructed from the other; ceases to be determinant and passes to the status of determinate $\mathrm{e}^{(5,7,11)}$. In the same way, meanings are elaborated by the subject in the relationship of interdependence with the other and with the collective ${ }^{(10)}$, which directs the need for knowledge about the meanings that elements of the same system attribute to one another. Based on the above, we ask: What meanings do nurse researchers and nursing assistants attribute to each other, as well as to the process of research development?

\section{OBJECTIVE}

This study aims to understand the meanings that nurse researchers and nursing assistants attribute to one another and to the development of research produced by Nursing.

\section{METHOD}

\section{Ethical aspects}

The research was approved by the Research Ethics Committee of the Escola de Enfermagem Anna Nery-EEAN/UFRJ, in the year 2014. This committee is linked to a Nursing School of a federal public university, located in the State of Rio de Janeiro - Brazil. Resolution 466/12 of the National Health Council (Conselho Nacional de Saúde) ${ }^{(12)}$ was met. Participation occurred on a voluntary basis, through the signing of the Informed Consent Term. The anonymity of the participants was kept anonymous, they were designated alphanumerically, according to the sample group of origin and the sequence of the interview. Thus, the $1^{\text {st }}$ group (NAn': Nursing Assistants), the $2^{\text {nd }}$ group (NRno: Nurse researcher) ${ }^{(13-14)}$.

\section{Theoretical-methodological framework}

The theoretical and methodological frameworks of the research were, respectively, the Complexity Theory ${ }^{(4)}$ and the Grounded Theory $(\mathrm{GT})^{(15)}$.

The Complexity Theory seeks to understand the phenomenon from the interaction between the elements that constitute $\mathrm{it}^{(4)}$. In this way, it favors the valorization of thought capable of broadening the understanding of a certain phenomenon beyond the sum of its parts, or of the linear relation between cause and effect. Therefore, it is pertinent to the delineation of the screen search.

As far as the methodological framework is concerned, GT is a method developed from a set of analytical procedures that, conducted in a systematic way, allow to develop a theoretical matrix that explains the phenomenon investigated ${ }^{(15)}$. In this sense, it favors the understanding of the factors that structure, condition and/or influence a phenomenon.

\section{Type of the study}

This is an explanatory research with qualitative approach.

\section{Methodological procedures}

The data that support this article were collected with two sample groups, namely: nursing assistants and nurses researchers; and validated by 13 judges, with 10 nurse researchers from different regions of Brazil and three nurse assistants. 
Regarding the research settings, it is pertinent to consider that, as a science in construction and social practice, Nursing has different areas of activity, where, for each of them, there may be peculiarities for the development of research, and for the convergence between scientific results and the assistance dimension ${ }^{(13)}$. However, from the foregoing and from the understanding that, in the group of human groups, a field of knowledge and intervention was sought that needs to be strengthened in the context of research training and development. This context of knowledge and intervention is adolescence. This assertion corroborates the scarcity of nursing research groups in Brazil for this area of knowledge compared to the other phases of the life cycle ${ }^{(16)}$.

Thus, the research settings were: for the group composed of nursing assistants, a Studies and Adolescent Health Care Center of a university hospital, in the capital of Rio de Janeiro. The activities developed in this center cover health care at the levels of primary, secondary and tertiary care, recommended by the Brazilian Unified Health System (SUS - Sistema Único de Saúde). For research nurses, as a setting, research groups registered at CNPq, linked to universities in Rio de Janeiro State ${ }^{(13)}$.

Inclusion criteria for the group of care nurses: time of professional experience in the current research setting (Study and adolescent health center of a university hospital), equal to or greater than one year; exclusion criteria: a nurse who was enrolled in the stricto sensu modality ${ }^{(13,17)}$.

For the group of nurse researchers, inclusion criteria were: having a doctorate's degree; to be linked to a research group registered in the National Council for Scientific and Technological Development (CNPq - Conselho Nacional de Desenvolvimento Científico e Tecnológico) ${ }^{(18)}$, with a line of research that approached the context of action of the nurses who composed the first sample group. Those whose experience in managing research was less than two years were excluded. Thus, 16 research participants were selected, being 10nursing assistants and six nurse researchers.

The selection of the participants was guided by the theoretical, non-probabilistic sampling of the GT, which consists of maximizing comparative opportunities of facts or incidents to determine how a category varies in terms of its properties and dimensions ${ }^{(15)}$. The data collection was finalized when reaching theoretical saturation, namely: when the categories presented explanatory density capable of responding to the research problem ${ }^{(13-14)}$.

Recruitment of nursing assistants was by convenience, using snowball technique. However, it should be noted that the use of this technique was limited to the process of capturing the participants that fit the inclusion and exclusion criteria.

In order to recruit the nurses researchers, a parametrized search was carried out in the Lattes Platform, in the field of the CNPq Research Groups Directory, using the refinement strategies described in the following table ${ }^{(13)}$ :

After selecting the research groups, each researcher was invited to participate in the study, through electronic correspondence, by the e-mail registered in the Curriculum Lattes ${ }^{(13)}$.

The semi-structured interview was used as a technique for data collection, carried out from October 2014 to March 2015(13), individually, and recorded in a digital medium. The interviews lasted, on average, 40 minutes. For the participants of the care nurse group, the following questions were asked: What is your perception about the nurse researcher? What is the relationship of this professional with his/her reality?; And, for the group of research nurses: What meanings do you assign to the care nurse to develop the research you do? Tell me, how do you understand this professional in the context of nursing research? In order to deepen the field of meanings, from the answers of the participants, circular questioning was performed in order to deepen questions pertinent to the object of the research. The interview sites were the settings previously described, in reserved environments. For the group of nurse researchers, the collection site was the teaching institution itself whose research group was linked ${ }^{(13)}$.

Chart 1 - Parameterized consultation for the recruitment of research groups, city of Rio de Janeiro, Brazil, 2017

\begin{tabular}{l}
\hline Groups recruitment: \\
\hline - Search term: "Adolescent", "Adolescents", "Adolescence"; \\
- Search option: "Any word". \\
\hline Other search filters: \\
\hline - Search option:"Name of the group"; \\
- Group situation:"Certificated"; \\
- Region:"Southeast"; UF:"Rio de Janeiro"; \\
- Knowledge area: Great area -"Health Sciences"; Area - "Nursing". \\
Source - Current base of the Research Groups Directory of the National Council for Scientific \\
and Technological Development - CNPq, Brazil (2015).
\end{tabular}

The data underwent the coding process which, in the GT, consists of a comparative analysis at three levels: open, axial and selective ${ }^{(12)}$. In open coding, the concepts were identified by comparisons between properties and dimensions of the data. At this stage, the preliminary codes emerged from the titles assigned for each incident, idea or event. The preliminary codes were grouped into conceptual codes ${ }^{(13,15)}$.

In the axial codification, the conceptual codes were grouped to form the categories and subcategories ${ }^{(12)}$. In this stage, the process of regrouping of the data that was separated in the open coding was initiated, aiming at a dense explanation of the phenomenon ${ }^{(13)}$.

The selective codification consisted in the comparison and analysis of the categories and subcategories, a process that is carried out in a continuous way that aims to develop the categories, to integrate and refine the theoretical matrix and to emerge the central phenomenon ${ }^{(15)}$.

The categories were ordered according to the paradigmatic model ${ }^{(15)}$, a scheme that allows explanatory coherence between the dimensions that support the theoretical matrix. Its structure is based on the components: phenomena, causal conditions, intervening conditions, context, action/interaction strategies and consequences ${ }^{(13)}$.

The results of the research were validated by 10 judges, namely: nurse researchers linked to research groups registered with CNPq, from different regions of the country, with expertise in the field of Adolescent Health and renowned experience in the management of research. In order to do so, the same strategy was used as described in Chart 01, increasing the refinement for all regions of Brazil ${ }^{(13)}$.

We sought to select researchers from research groups from each Brazilian macro-region, ie: South, Southeast, North, Northeast and Center-West. The latter was not considered because there was no return of the selected group. The distribution of judges by region resulted in: three from the North, three from the Northeast; one from the Southeast, three from the South of Brazil(13). 
In order to select the groups from which the judges emerged, the analysis of the human resources of the groups was established as a criterion, based on the data contained in the group's information, contained in the CNPq Research Groups Directory, as well as the scientific production of the judges selected, especially the insertion in research projects as coordinators ${ }^{(13)}$.

The material for validation consisted of a compact booklet in two components: the summary of the research results and the validation tool. In the latter, the following criteria were used: Analysis (ability of a conceptual model to fit the reality investigated); Understanding (ease of understanding the meanings that concepts signal) and theoretical generalization (ability to make a conceptual model applicable in similar contexts from which the phenomenon investigated emerges) ${ }^{(13,19)}$. Each judge could describe his/her evaluation, taking as possibilities: totally corresponds, corresponds partially, and does not correspond. For any option, it was necessary to justify the answer ${ }^{(13)}$.

For the first phase of the validation (nurses researchers), a space (room) at the $18^{\text {th }}$ National Seminar on Nursing Research (SENPE - Seminário Nacional de Pesquisa em Enfermagem), which took place in Fortaleza, CE, was made available as an axis of connection between judges and research coordinator, Brazil, in June 2015, whose main theme was "Nursing research: applicability, implications and visibility". The judges who could not attend, sent the material analyzed, via correspondence, to the researcher ${ }^{(13)}$.

The second phase of the validation process occurred in the same setting as the participants of the second sample group of the study [Núcleo de Estudos e Atenção à Saúde do Adolescente (Studies and Adolescent Health Care (enter)], with three nursing assistants who had not been interviewed during the data collection phase.

\section{RESULTS}

The results derive from the theoretical matrix supported in the doctoral thesis "Gestão do Conhecimento Científico: conexões entre a pesquisa e o gerenciamento do cuidado de enfermagem no contexto da adolescência", in which the central phenomenon was outlined in "Conexões para uma ciência viva da enfermagem".

This phenomenon considers the science of Nursing in a system perspective, permeated by meanings and actions that drive and order the development of research and its connections with social demands. However, by virtue of theoretical density, this article contemplates the category that, in the use of the paradigmatic model[ ${ }^{(13)}$, is configured as an intervening condition for the development of research and connections between science and the praxis of Nursing.

Therefore, the category"Nursing care and nurse researcher: construction and projection of polymorphous identities" is presented, based on the subcategories: Scientific research on the perception of nursing assistants and nurses researchers: multifaceted meanings; and Implications of the perception about Nursing care practice and research: between orders and disorders. Thus, the first subcategory.

\section{Scientific research on the perception of nursing assistants and nurses researchers: multifaceted meanings}

The meanings that nursing assistants ascribe to the researcher nurses, in the investigated context, reveal themselves in a negative way, at the point of perceiving them as distinct elements of the same system. Among the possible consequences of this reality may be the devaluation of research and research nurse.

We put a very bad load on the researcher [...]. Oh, he's not a nurse anymore. He's a doctor now! But, wait a minute, he's a doctor in nursing. Oh, no! But he does not do anything else in nursing. (NA1)

I do not see this professional. [The Nurse researcher] [...] / do not think nurses take very seriously what other nurses do, you see that the doctor "so-and-so" the guys already open their eyes, but for the nurse, but also depends a lot on the nurse. (NA2)

On the other hand, the nurse researchers recognize limitations and conditions so that the care nurse can consume the research. In addition, there is an indication that, from the perspective of these researchers, the care nurse himself/herself does not know that his/her practice is based on science.

[...] some nurses have greater resistance to research and possible changes. (NR1)

[...] he will read this article only when he is obliged to read it [...]. I think, regarding nurses, that they do not have this habit. (NR3)

[...] sometimes the nurse thinks he is not doing a scientifically sound clinical practice, but he is. When he is asked why he is doing it that way, he may think it is not science, but it is science. (NR4)

The divergence between what is or what serves the scientific research in nursing seems to reflect in the misperception about the purpose and importance of the masters and doctorate. Therefore, even though it did not contemplate a generalized projection, this reality was considered in the results of the research, when portraying the limiting objectives of nursing assistants in graduate studies, in the stricto sensu modality.

I see this reality a lot [...] they are close to retiring and they want to do the master's degree in order to earn a little more. Solsee that this interest is not in improving one's practice, but is limited to financial. (NR1)

I can see that not everyone can understand that the masters and doctorates go far beyond a title. I can say: I'm a doctor, so what? What does the person do with the title? The title by itself does not mean this construction [...] I have acquaintances who want to do the masters or the doctorate because they want to retire. (NR3)

[...] / realize that the motivation for research and doctorate is very focused on the financial issue, it has the issue of status as well, but it is mainly by the financial one. I do not think this is a bad reality, I think even this incentive is important, but the desire to change the practice has to be a priority. (NR6)

In the logic of the senses, in their possibilities of apprehension of the objective reality, they permeate conditioning factors, facilitators or determinants to organize the thought about what one wishes to understand. However, this organization is not always processed in the field of ideas, reflecting, therefore, the Implications of the perception about Nursing care practice and research: between orders and disorders, second subcategory. 
Implications of the perception about Nursing care practice and research: between orders and disorders

Nursing assistants base the understanding for scientific research/development based on the mechanism of comparison and differentiation between Nursing and other professional categories, as demonstrated in the following sections:

Ioften compare [...] / think you can see when you compare. It is different, for example, in medicine because when they produce research it is to change something, some procedure that is being done, change a way of thinking, create new concepts. In fact, it changes! (NA3)

[...] I think there is not much interest (for the research), it is more with the Medicine issue, at least I do not see, only if there is somewhere and I do not see. (NA2)

You realize scientific development in other professions, scientific advances, they are reflected in practical action, but nursing, in a way, I see it paralyzed. (NA5)

Despite this, nursing assistants understand the importance of research for their work process:

Research is fundamental to nurses' practice, because they have to know, be up to date. (NA4)

I see it as something very important to us, very much, but it is still far. (NA6)

On the other hand, in addition to the challenges for the progress of nursing science, the nurse researchers recognize the historical process of scientific evolution of their profession and rely on this knowledge to understand the challenges of Nursing in the face of the dynamics of science and its developments in the fields of Power Culture, Human Resource Formation and Knowledge Management.

This dialectic of thinking and doing came with the graduate course, but we still have a lot to go forward. (NR2)

You have to see the story and see that there is a context. Thank God this has been changing. Before, the doctor knew that the nurse was his assistant and today it is very clear that this is not so, that he is a member of a multiprofessional team. I spoke of the context, I compared medicine to say that nursing comes from a culture of low esteem [...]. To change this is through knowledge, through studies. (NR3)

We have already lived in a time where the most important thing was to produce knowledge [...] welearned that the rigor of the method is essential, but we needed to move forward, we discovered that it was not enough to produce the dissertation or thesis, then we discovered that it was notenough just to publish, we had to disseminate. Scientific meetings have become privileged spaces for the dissemination of knowledge, so we stop to think: this is not enough! [...]. In this way, we also take the research to the formulators of public policies. (NR4)

The progress of Nursing, as a science under construction, brings with it emergent challenges that can reflect in the scientific stagnation, in spite of the epistemological obstacles inherent to the system of scientific production and dissemination. In this course, it brings elements related to academic productivism as a point of stagnation for the connections between research/ assistance - science/praxis, as shown in the following sections:

Sometimes I tell the students of the residency that it looks like a factory of scientific productions and, in fact, the person only produces article [...] but l ask: modified what? (EA8)

The goal would be we producing for nurses, so then they could improve patient care, this would be the goal, but there is a strong guideline of the development agencies we are producing to meet the classification of a course, or a journal classification. Only for that?! [...] That is what we have to think about now. We are in a period when we are stopping to think. (NR2)

For whom do we produce?! For ourselves, unfortunately it is for ourselves [academic sphere]. (NR5)

The interests are different; the system induces me to publish, so I already consume an article thinking about one publication, the next publication and the other publication. So we are living a "boom" of nursing publications [...] the distance is there: I have to produce, produce, produce, but for what purpose? How does this production impact the practice? (NR6)

Academic productivism, therefore, is conceived as a phenomenon that distances nursing research from the reality of care. It is clear from this reality that the gap between research results and nursing care is not limited to the lack of interest of this professional to consume up-to-date science, or for the same purpose, to the organizational dynamics of work in which it is inserted.

\section{DISCUSSION}

In considering the intersubjectivity involved in the projection of meanings and perceptions, it is necessary to point out, as an element imbued in this process, the comparison relation with which nursing assistants establish with other professions, especially Medicine, to describe the way they conceive the scientific framework of the Nursing work process in relation to other professionals.

However, it should be pointed out that the valuation of scientific knowledge for professional performance is influenced by organizational culture, historical and political aspects; in addition, the capacity of convergence of products and technological processes in work practices (20-22). At this juncture, it is possible to consider that the consumption of research presents a relation that crosses the subjective dimension, while, also, it finds resonance in the objective capacity of implementing this knowledge in the labor practices.

Thus, to contextualize this phenomenon implies understanding the sociology of the professions and understanding that nursing, as a science under construction, is recent ${ }^{(23)}$. However, it emerges, in its modern conformation, from the production of specific and total knowledge for the foundation of its practice ${ }^{(24)}$. What makes this emerging challenge not, therefore, is its starting point, which comes with Florence Nightingale, but the expansion of its demands in the face of globalization based on science, innovation, and technology that permeates health and care systems. Regarding this, the nurse researchers - participants in this research - highlight 
the historical/scientific evolution of Nursing with prospects favorable to professional development and consolidation in the field of Sciences, fact supported by literature ${ }^{(25-26)}$.

In this sense, since the second half of the twentieth century, in a global projection, modern nursing has presented an expressive overview in the evolution of its human capital, based on the knowledge society and, consequently, in the production and dissemination of scientific research. In Brazil, this growth took place at the end of the $20^{\text {th }}$ century, and was intensified in the first decade of the $21^{\text {st }}$ century, following the expansion of the Stricto Sensu Gaduate Programs ${ }^{(25-26)}$. However, if there was an evolution in intellectual production, there is an intensified need for connections between these productions and changes in Nursing work practices ${ }^{(27)}$, as shown by the data.

Among the challenges for these connections is the rupture of the frail vision about the importance of scientific research to the nursing dimension of care, from the return of the scientific results to the settings from which the need for research emerged, as well as for the related settings ; however, it is necessary to invest in possibilities of dissemination that go beyond the isolated mode of producing scientific articles ${ }^{(28)}$, as well as strategies that allow the convergence of explicit knowledge (formalized, printed and registered via scientific production) into tacit knowledge to the individual, internalized and processed from his/her worldview) ${ }^{(29)}$.

This movement may favor the projection that the nursing assistant assigns to the researcher and the researcher and, thus, may imply the implementation of research results in their work process $^{(2)}$. In fact, the researcher may develop possibilities to better design his/her research with a view to the inherent nature of his/ her objects and results in the assistance dimension. It is possible that the result of this process influences the reorientation of polymorphous identities and realities, in order to impact the scientific and technological evolution of Nursing and, consequently, the quality of assistance to individuals/groups/collectivities.

On the other hand, the data point to issues of concern for scientific and human capital development, in that they point to two counterproductive mechanisms to the progress of Nursing science and its relation to social demands, namely: academic productivism ${ }^{(30-31)}$ as a point of stagnation for the connections between research and assistance, and the movement of insertion in the stricto sensu disconnected of the real demands of the profession and of the society, motivated, mainly, by the subsidized financial incentive in the plan of positions and careers.

About academic productivity, it is worth mentioning that this diverges from what is understood by productivism. The first, strictly speaking, corresponds to the set of officially instituted and shared rules that give value to the dissemination of science in a global scope from the publication, with emphasis on the articles, as evaluation criteria to the hierarchy system to the Stricto Sensu Graduate Programs and individually to the researcher, as an important parameter for the distribution of resources and professional recognition; the second involves, deliberatively, more ethical and legal conduct that drives actions/strategies to increase productivity, among which: plagiarism, self-plagiarism, falsification of results, co-autorship of façade, among others ${ }^{(32)}$.

It is known, however, that the academic productivity in Brazilian Nursing has been progressive in recent years, since taking the current aspects of evaluation for the dissemination and consumption of research, expressively quantitative(33), Nursing, in the triennium of 2007 -2009 obtained 5,194 articles, in 595 periodicals, presenting, therefore, progress of about $30 \%$ in relation to the quantitative of productions in the previous triennium. In the triennium 2010-2012, the amount of scientific production of Nursing was even more significant, in which 9,206 articles were registered, a $77.2 \%$ increase over the previous triennium ${ }^{(34)}$.

Faced with this phenomenon, it is the following reflection: Is Science, in its system of academic production, serving whom? Our society or our self-production among its peers? ${ }^{(33)}$. In the meantime, it reinforces the questioning of the ways in which science has, in fact, contributed to the dimension of the Nursing work process.

Thus, the parameters for evaluating the dissemination of research results do not reach evaluative possibilities of how such products and processes reverberate in practice ${ }^{(30-36)}$, signaling the need for strategies that make it possible to diagnose this relationship and, above all, intervention to connect the assistance and academic dimensions, so as to reflect on positive impacts to Nursing.

The current system of scientific diffusion adopts a linear relation in which the published scientific article happens to qualify for potential citation; therefore, when this article is quoted, it is understood that the research has been disseminated ${ }^{(36-37)}$. However, this mechanism is far from the objective reality, due to the gap between the information accessed, processing/construction/incorporation of knowledge and their implementation in the work process.

The data of this research, revealing the academic productivism as a counterproductive phenomenon to the progress of Nursing as a science under construction, are in keeping with the worrisome signs, punctuated in the literature, that pass through the area of knowledge of interest of Nursing, since the system of scientific knowledge has lost its use value to the exchange value, thus triggering market characteristics in the field of scientific production ${ }^{(30,32-33)}$.

This system gains alarming proportions in the face of productivism, but also finds naturalized roots in the overview of productivity required and fostered by the policies that govern Stricto Sensu Graduate Programs and, consequently, the formation of intellectual capital and the academic trajectory of researchers. Part of this process emerges from the methods and strategies of impact assessment of scientific production, which constitute scientometry ${ }^{(30-33,37)}$.

Still on the relation productivity/scientific productivism, it is worth to point out that the existence of these phenomena should not serve as a buffer that justifies the absence or commitment with the production and dissemination of scientific knowledge at a desirable level and recommended for a science under construction. That said, the importance of the scientific process in undergraduate education is emphasized, especially by the professor doctors inserted in this conjuncture, in order to break the logic that only professor doctors accredited in Graduate Programs must produce science, since knowledge is legitimized when it produces new knowledge, where learning is a permanent exercise of authorship ${ }^{(38)}$.

\section{Study limitations}

It is pertinent to highlight a limiting factor of the study, which is based on the research setting, because the spheres of the private health service and higher education institution can confer different 
realities about the meanings that the nurses attribute to the research development. Moreover, although the field of Adolescent Health Care was delimited as a research context, the data indicated a transversal character of this setting, so as not to be specificity. This suggests that this research be replicated in other settings.

\section{Contributions to the sector of Nursing}

The results of the research contribute to the understanding of the Nursing Science development system, as it makes possible to think about the interactions between nursing careers and nurse assistants. In this glance, it could strengthen the scientific praxis of nurses and, therefore, qualify nursing care in the face of the current challenges of science in its technological and innovation developments, from the production and consumption of up-to-date knowledge.

\section{FINAL CONSIDERATIONS}

The results showed that the meanings attributed to the research are also influenced by the dynamics of the production system and academic productivism. Consequently, the (lack of) valorization, the (lack of) interest and the (lack of) motivation to incorporate research into the care practice are influenced by the meanings in which the attending nurse and the research nurse attribute to each other, as well as to the science of Nursing.

These issues contribute to the distance between scientific research and the nursing care dimension, and, in the same logic, between nurse assistants and nurse researchers. From this process, seemingly distant realities appear from the same system that, in a recursive relation of complexity, increasingly potentiates this gap when the relations between the actors that make up this system occur in an inconsistent way.

It is clear from this reality that the interactions between nurse researchers and nursing assistants in the field of Perceptions are constituted in an intersubjective character, whose distancing may imply the construction and maintenance of polymorphous identity. This phenomenon seems to suffer expressive influences from the convergent and divergent movements in which the research nurse performs in the work context of the care nurse and vice versa.

\section{REFERENCES}

1. Rezende FC. [Transformations in scientificity and the inferential adjustment in political science: argument and evidence in the publications with high impact factor]. Rev Sociol Polit [Internet]. 2017 [cited 2017 Nov 10];25(63):103-38. Available from: http://dx.doi. org/10.1590/1678-987317256305

2. Alvim NAT. Convergent care research in nursing - opportunities for technological innovations. Esc Anna Nery [Internet]. 2017 [cited 2017 Oct 14];21(2):e20170041. Available from: http://dx.doi.org/10.5935/1414-8145.20170041

3. Meleis Al. My wish for a global research agenda in nursing. Rev Lat Am Enfermagem [Internet]. 2015 [cited 2017 Oct 14];23(4):569-70. Available from: http://dx.doi.org/10.1590/0104-1169.0000.2589. English, Portuguese, Spanish.

4. Morin E. Ciência com consciência. 13 ed. Rio de Janeiro: Betrand; 2010. 350 p.

5. Santos EG, Sadala MGS. Alteridade e adolescência uma contribuição da psicanálise para a educação. Educ Real [Internet]. 2013 [cited 2017 Nov 10];38(2):555-68. Available from: http://seer.ufrgs.br/educacaoerealidade/article/view/35445

6. Thones APB, Pereira MA. Um entre o outro e eu: do estranho e da alteridade na educação. Educ Real [Internet]. 2013 [cited 2017 Nov 10];38(2):501-520. Available from: http://www.scielo.br/pdf/edreal/v38n2/v38n2a09.pdf

7. Peppino S. Linguage la pragmática trancedental de Apel y el psicanalises de Lacan: planteo de alguns discusiones preliminares. Estud Fislos Pract Hist Ideas [Internet]. 2015 [cited 2017 Nov 11];17(2):69-75. Available from: http://www.scielo.org.ar/scielo.php?script=sci_arttext\&pid $=$ S1851-94902015000200007

8. Leão ER, Farah OG, Reis EAA, Barros CG, Mizoi CS. Academic profile, beliefs, and self-efficacy in research of clinical nurses: implications for the Nursing Research Program in a Magnet JourneyTM hospital. Einstein [Internet]. 2013 [cited 2017 Nov 10];11(4):507-13. Available from: http://dx.doi.org/10.1590/S1679-45082013000400018. English, Portuguese.

9. Ortega MCB, Cecagno D, Llor MAS, Siqueira HCH, Soler LM. Academic training of nursing professionals and its relevance to the workplace. Rev Lat Am Enfermagem [Internet]. 2015 [cited 2017 Oct 21];23(3):404-10. Available from: http://dx.doi.org/10.1590/0104-1169.0432.2569. English, Portuguese, Spanish.

10. Santos GL, Chaves AM. Compartilhamentos e singularizações: a constituição social da subjetividade. Psicol Argum [Internet]. 2013 [cited 2017 Nov 11];31(74):569-80. Available from: http://www2.pucpr.br/reol/pb/index.php/pa?dd1=12247\&dd99=view\&dd98=pb

11. Cechin MEB. Discontinuidades em los programas de investigación cinetificos de Freud y Lacan em torno al "aparato del lenguage". Ajayu [Internet]. 2015 [cited 2017 Nov 11];13(1):27-38. Available from: http://www.redalyc.org/articulo.oa?id=461545455002

12. Ministério da Saúde (BR), Conselho Nacional de Saúde. Resolução n. 466, de 12 de dezembro de 2012. Aprova diretrizes e normas regulamentadoras de pesquisas envolvendo seres humanos [Internet]. Brasília: Ministério da Saúde (BR); 2012 [cited 2015 Oct 20]. [about 03 screens] Available from: http://bvsms.saude.gov.br/bvs/saudelegis/cns/2013/res0466_12_12_2012.html

13. Silva ÍR, Leite JL, Trevizan MA, Silva TP, José SAP. Connections between research and health care assistance: emerging challenges for science, innovation and technology in nursing. Texto Contexto-Enferm [Internet]. 2017 [cited 2018 Aug 7];26(4):e2470016. Available from: http:// dx.doi.org/10.1590/0104-07072017002470016 English, Portuguese. 
14. Silva ÍR, Leite JL, Trevizan MA, Mendes IAC, Silva TP, Lins SMSB. Learning through research: from teaching science to the sphere of nursing care. Esc Anna Nery [Internet]. 2017 [cited 2018 Aug 7]; 21(4):e20160329. Available from: http://dx.doi.org/10.1590/2177-9465ean-2016-0329. English, Portuguese

15. Strauss AL, Corbin J. Pesquisa qualitativa: técnicas e procedimentos para o desenvolvimento de teoria fundamentada. 2a ed. Porto Alegre (RS): Artmed; 2008. 288p.

16. Christoffel MM, Souza TV, Silveira ALD, Valente EV, Meirelles JR, Silva PL. [Nursing research groups in the area of newborns, children, and adolescents: profiles and trends]. Texto Contexto-Enferm [Internet]. 2011 [cited 2017 Oct 28];20(Esp):147-55. Available from: http://dx.doi. org/10.1590/S0104-07072011000500019 Portuguese.

17. Silva ÍR, Silva TP, Ferreira MJC, José SAP, Leite JL. The work context and the intervenient factors for the consumption of research by clinical nurses. Cogitare Enferm [Internet]. 2018 [cited 2018 Aug 7];23(2):e53447. Available from: https://revistas.ufpr.br/cogitare/article/ view/53447. English, Portuguese.

18. Conselho Nacional de Desenvolvimento Científico e Tecnológico (CNPq). Diretório dos Grupos de Pesquisa [Internet]. Brasília: CNPQ; 2018 [cited 2014 Mar 02]. Available from: http://lattes.cnpq.br/web/dgp

19. Souza SS, Silva DMGV. Validation of a theoretical model: knowing the interactive processes within the support network for people with tuberculosis. Acta Paul Enferm [Internet]. 2011 [cited 2017 Jan 18];24(6):778-83. Available from: http://dx.doi.org/10.1590/S010321002011000600008 English, Portuguese.

20. Ruas TL, Pereira L. [How to build Science, Technology, and Innovation Indicators using Web of of Science, Derwent World Patent Index, Bibexcel, and Pajek?] Perspect Ciênc Infor [Internet]. 2014 [cited 2017 Nov 11];19(3):52-81. Available from: http://dx.doi.org/10.1590/19815344/1678. Portuguese.

21. Loray R. Políticas públicas em ciência, tecnologia e innovación: tendências regionales y espacios de convergência. Rev Estud Soc [Internet]. 2017 [cited 2017 Nov 12];62(1):62-80. Available from: https://dx.doi.org/10.7440/res62.2017.07

22. Silva RC, Ferreira MA. [Technology in nursing care: an analysis from the conceptual framework of Fundamental Nursing]. Rev Bras Enferm [Internet]. 2014 [cited 2017 Nov 10];67(1):111-8. Available from: http://dx.doi.org/10.5935/0034-7167.20140015. Portuguese.

23. Carvalho, V. [For an epistemology of nursing care and the educational development of the subjects of knowledge in nursing area - a philosophical point of view]. Esc Anna Nery [Internet]. 2009 [cited 2017 Oct 28];13(2):406-14. Available from: http://www.scielo.br/pdf/ean/ v13n2/v13n2a24. Portuguese.

24. Bellaguarda MLR, Padilha MI, Pereira Neto AF, Pires D, Peres MA. [Reflection on the legitimacy of the autonomy at nursing in the field of the health professions in the light of Eliot Freidson's ideas]. Esc Anna Nery [Internet]. 2013 [cited 2017 Oct 28];17(2):369-74. Available from: http://dx.doi.org/10.1590/S1414-81452013000200023. Portuguese.

25. Htale VA, Moreira COF, Bochner R, Leal MC. Professional paths of alumni from doctorate programs in health and biological sciences. Rev Saúde Pública [Internet]. 2014 [cited 2017 Oct 28];48(1):1-9. Available from: http://dx.doi.org/10.1590/S0034-8910.2014048004629

26. Suazo SV, Sanhueza-Alvarado S. Doctorate in nursing in chile: a path not without its difficulties. Rev Lat Am Enfermagem [Internet]. 2015 [cited 2017 Oct 28];23(3):379-86. Available from: http://dx.doi.org/10.1590/0104-1169.0634.2568. English, Portuguese, Spanish.

27. Montesinos MJL, Soler LM. Doctorate nursing degree in Spain. Rev Lat Am Enfermagem[Internet]. 2015 [cited 2017 Oct 28];23(3):372-78. Available from: http://dx.doi.org/10.1590/0104-1169.0512.2567. English, Portuguese, Spanish.

28. Scochi CGS, Gelbcke FL, Ferreira MA, Lima MADS, Padilha KG, Padovani NA, Munari DB. Nursing doctorates in Brazil: research formation and theses production. Rev Lat Am Enfermagem [Internet]. 2015 [cited 2017 Nov 28];23(3):387-94. Available from: http://dx.doi. org/10.1590/0104-1169.0590.2564. English, Portuguese, Spanish.

29. Takeuchi H, Nonaka I. Gestão do conhecimento. Porto Alegre: Bookman, 2008. 320 p.

30. Leite JL. [Publish or perish: the puzzle of academic productivism]. R Katálysis [Internet]. 2017 [cited 2017 Nov 16];20(2):207-15. Available from: http://dx.doi.org/10.1590/1982-02592017v20n2p207. Portuguese.

31. Vosgerau DSR, Orlando EA, Meyer P. [Academic productivism and its repercussions in the professional development of professors]. Educ Soc [Internet]. 2017 [cited 2017 Nov 16];38(138):231-47. Available from: http://dx.doi.org/10.1590/es0101-73302016163514. Portuguese.

32. Vilaça MM, Palma A. [Dialogue on scientometrics, malaise in the academy and the controversy about productivism]. Rev Bras Educ [Internet]. 2013 [cited 2017 Oct 28];12(53):467-500. Available from: http://dx.doi.org/10.1590/S1413-24782013000200013. Portuguese.

33. Akerman M. Measures of experience and scientometrics to evaluate the impacto f scientific production. Rev Saúde Pública [Internet]. 2013 [cited 2017 Oct 28];47(4):824-28. Available from: http://dx.doi.org/10.1590/S0034-8910.2013047004756

34. Scochi CGS, Munari DB, Gelbke FL, Ferreira MA. The challenges and strategies from graduate programs in nursing for the dissemination of scientific production at international journals. Esc Anna Nery [Internet]. 2014 [cited 2017 Oct 28];18(1):5-10. Available from: http://dx.doi. org/10.5935/1414-8145.20140001. English, Portuguese, Spanish.

35. Golveia FC. Altmetrics and the interface between science and society. Trab Educ Saúde [Internet]. 2016 [cited 2017 Nov 10]; 14(3):646-8. Available from: http://dx.doi.org/10.1590/1981-7746-sip00126

36. Vanti N, Casado ES. [Altmetrics: social media metrics for a more democratic science]. Transinformação [Internet]. 2016 [cited 2017 Nov 10];28(3):349-58. Available from: http://dx.doi.org/10.1590/2318-08892016000300009 Portuguese. 
37. Jardim, JB. Adoption, citation, and diffusion of scientific articles: what is diffused? Psicol USP [Internet]. 2011 [cited 2017 Oct 28];22(2):35766. Available from: http://dx.doi.org/10.1590/S0103-65642011005000015

38. Demo, P. Aprender como autor. São Paulo (SP): Atlas; 2015. 208p. 